\title{
IDENTIFIKASI BAKTERI PADA DEPOT AIR MINUM ISI ULANG DI KOTA MANADO
}

\author{
${ }^{1}$ Perisai P. Rumondor \\ ${ }^{2}$ John Porotu'o \\ ${ }^{2}$ Olivia Waworuntu
}

\author{
${ }^{1}$ Kandidat Skripsi Fakultas Kedokteran Universitas Sam Ratulangi Manado \\ ${ }^{2}$ Bagian Mikrobiologi Fakultas Kedokteran Universitas Sam Ratulangi Manado \\ Email: Perisairumondor10_019@yahoo.com
}

\begin{abstract}
Water is a chemical compound that has a very important role for the life of humans and other living creatures but also serve as a medium of transmission of diseases. Refillable drinking water has become a common choice for the people in Indonesia, including in the city of Manado. One of the diseases caused by drinking poor quality water is diarrhea. To determine the condition of the contaminated refillable drinking water, a research or clinical testing in the laboratory is needed. The purpose of this research was to determine the pattern of bacteria in refillable drinking water. This study uses a descriptive research method with a cross sectional approach. Samples were taken from 20 refillable drinking water depots in Manado city that have met the inclusion criteria. Identification of bacteria performed with the culture medium. The results showed 4 samples contained gram positive bacteria, 5 samples contained gram negative bacteria and 11 samples contained a mixture of gram positive and gram negative. Gram positive bacteria consists of three species which are Bacillus subtilis (14 samples; 42,42\%), Streptococcus spp. (1 sample; 3,03\%) and Staphylococcus spp. (1 sample; 3,03\%) and. Six species of gram negative bacteria which are Shigella (1 sample; 3,03\%), Diplococcus (1 sample; $3,03 \%$ ), Enterobacter cloacae (2 samples; 6,06\%), Enterobacter agglomerans (2 samples; 6,06\%), Pseudomonas spp. (4 samples; $12,12 \%$ ), and Proteus vulgaris ( 7 samples; 21,21\%). The conclusion of this research most types bacteria of found were Bacillus subtilis.
\end{abstract}

Keywords: bacteria, refillable drinking water

Abstrak: Air merupakan senyawa kimia yang sangat penting fungsinya bagi kehidupan umat manusia dan mahkluk hidup lainnya tapi juga dapat berperan sebagai media penularan penyakit. Air minum isi ulang telah menjadi pilihan umum masyarakat Indonesia, termasuk di kota Manado.Salah satu penyakit yang disebabkan oleh air minum yang kualitas mikrobiologisnya buruk adalah diare.Untuk mengetahui kondisi terkontaminasi tidaknya air minum isi ulang diperlukan penelitian atau pengujian secara klinis di laboratorium.Tujuan dari penelitian ini adalah untuk mengetahui pola bakteri pada air minum isi ulang. Penelitian ini menggunakan metode penelitian deskriptif dengan pendekatan cross sectional. Sampel diambil dari 20 depot air minum isi ulang di Kota Manado yang telah memenuhi kriteria inklusi. Identifikasi bakteri dilakukan dengan media kultur. Hasil penelitian menunjukkan 4 sampel terdapat bakteri gram positif, 5 sampel terdapat gram negatif dan 11 sampel terdapat campuran bakteri gram positif dan gram negatif.Bakteri gram positif terdiri dari 3 spesies yaitu Bacillus subtilis (14 sampel; 42,42\%), Streptococcus spp. (1 sampel; 3,03\%)dan Staphilococcus spp. (1 sampel; 3,03\%). Enam bakteri spesies gram negatif yaitu Shigella (1 sampel; 3,03\%), Diplococcus (1 sampel; 3,03\%), Enterobacter cloacae (2 sampel; 6,06\%), Enterobacter agglomerans (2 sampel; 6,06\%), Pseudomonas spp. (4 sampel; 12,12\%) dan Proteus vulgaris (7 sampel; 21,21\%). Kesimpulan pada penelitian ini jenis bakteri terbanyak yang ditemukan adalahBacillus subtilis.

Kata Kunci: bakteri, air minum isi ulang 
Air merupakan senyawa kimia yang sangat penting fungsinya bagi kehidupan umat manusia dan mahkluk hidup lainnya. ${ }^{1}$ Air yang dibutuhkan manusia meliputi air layak pakai yang bersih dan sehat untuk keperluan memasak, mencuci, dan mandi serta air yang layak konsumsi untuk keperluan minum. ${ }^{2}$ Air juga dapat berperan sebagai media penularan penyakit. Air merupakan media dan lingkungan yang baik untuk kehidupan mikroorganisme baik itu mikroorganisme patogen maupun non patogen, oleh karenanya timbul pengertian apa yang disebut water borne disease. ${ }^{3}$

Air minum adalah air yang melalui proses pengolahan atau tanpa proses pengolahan yang memenuhi syarat kesehatan dan dapat langsung diminum. ${ }^{4}$ Air minum aman bagi kesehatan apabila memenuhi persyaratan fisika, mikrobiologis, kimiawi, dan radioaktif., ${ }^{4,5}$ Parameter wajib penentuan kualitas air minum secara mikrobiologi adalah total bakteri Coliform dan Escherichia coli. ${ }^{5}$

Pemenuhan kebutuhan air minum masyarakat saat ini sangat bervariasi. Di kota besar, dalam hal pemenuhan kebutuhan air minum masyarakat juga mengkonsumsi air minum dalam kemasan (AMDK), karena praktis dan dianggap lebih higienis. AMDK diproduksi oleh industri melalui proses otomatis dan disertai dengan pengujian kualitas sebelum diedarkan ke masyarakat. Pada beberapa tahun terakhir ini masyarakat merasa bahwa AMDK semakin mahal, sehingga muncul alternatif lain yaitu air minum yang diproduksi oleh depot air minum isi ulang (DAMIU). ${ }^{6}$ DAMIU adalah badan usaha yang mengelola air minum untuk keperluan masyarakat dalam bentuk curah dan tidak dikemas. ${ }^{6,7}$

Air minum isi ulang (AMIU) telah menjadi pilihan umum masyarakat Indonesia, termasuk di kota Manado. Berbagai penelitian sebelumnya di berbagai kota besar di Indonesia, menunjukkan AMIU kurang aman atau terkontaminasi dengan bakteri yang dapat merugikan kesehatan manusia. Penelitian yang dilakukan oleh Institute Pertanian Bogor (IPB) dan Badan Pengawas Obat dan
Makanan (BPOM) menyatakan bahwa sebagian besar produk air minum dihasilkan oleh DAMIU tidak memenuhi standar industri air minum dalam kemasan. Penelitian dilakukan dibeberapa kota besar seperti Jakarta, Bandung, Medan dan Surabaya. Hasil penelitian didua lembaga ini menunjukan bahwa air minum isi ulang terkontaminasi bakteri Coliform, E. Coli, salmonella, dan bahkan sampel air terdeteksi mengandung logam berat kadmonium. ${ }^{8}$ Penelitian yang dilakukan oleh Risky, Bobby dan Sammy pada 3 depot air minum isi ulang di Kota Manado yang diperiksa, semuanya tidak memenuhi persyaratan kualitas air minum karena sudah terkontaminasi dengan bakteri Coliform. ${ }^{6}$

Salah satu penyakit yang disebabkan oleh air minum yang kualitas mikrobiologisnya buruk adalah diare. ${ }^{5}$ Penyakit diare termasuk dalam penyakit yang menonjol di Sulawesi Utara dengan menduduki peringkat ke 2 dan dengan jumlah kasus 32.589 pada tahun 2008. Prevalensi kasus diare yang ditemukan di kota Manado sebesar 3,1\%. ${ }^{6,9}$

Mengingat semakin banyaknya penggunaan dan pemanfaatan AMIU untuk kebutuhan vital masyarakat dan adanya indikasi kurang amannya AMIU di beberapa kota besar di Indonesia, maka perlu adanya pengawasan atau monitor serta pengujian yang memadai atas keamanan AMIU yang beredar di kota Manado. Hal ini diperlukan karena masyarakat tidak dapat melihat secara nyata kondisi aman tidaknya AMIU yang dikonsumsi di kota Manado. Untuk mengetahui kondisi terkontaminasi tidaknya AMIU diperlukan penelitian atau pengujian secara klinis di laboratorium. Di samping itu, penelitian ini diperlukan mengingat intervensi pemerintah untuk mengawasi ketersediaan AMIU yang bersih dan aman kurang memadai. Masyarakat juga pada umumnya kurang memberi perhatian dan pertimbangan rasional menyangkut keamanan dan higienitas AMIU karena yang menjadi pertimbangan utama adalah harga yang terjangkau.Hal ini juga didorong oleh kondisi dimana ketersediaan air minum yang bersih dan aman kurang tersedia. 
Rumondor, Porotu'o, Waworuntu; Identifikasi Bakteri pada Depot Air...

Berbagai hal dan kondisi tersebut, menjadi landasan utama yang melatar belakangi untuk melakukan penelitian tentang identifikasi bakteri pada air minum isi ulang yang ada di kota Manado.

\section{METODE PENELITIAN}

Penelitian yang dilakukan bersifat deksriptif prospektif. Penelitian ini dilakukan dari bulan Januari sampai Februari 2014. Sampel pada penelitian ini adalah 64 depot air minum isi ulang di Kota Manado berdasarkan rumus slovin tapi berhubung dengan jumlah waktu yang terbatas maka peneliti hanya dapat mengambil 20 sampel. Sampel yang diambil telah memenuhi kriteria inklusi yaitu depot air minum isi ulang yang terdaftar di Dinas Kesehatan. Pengelolaan sampel dilakukan di Laboratorium Mikrobiologi Fakultas Kedokteran UNSRAT.

\section{HASIL PENELITIAN}

Penelitian ini dilakukan di Laboratorium Mikrobiologi Fakultas Kedokteran Universitas Sam Ratulangi Manado terhadap 20 sampel ditemukan 4 sampel bakteri gram positif, 5 sampel bakteri gram negatif dan 11 sampel terdapat bakteri gram positif dan negatif.

Tabel 1. Hasil pewarnaan gram

\begin{tabular}{lcc}
\hline \multicolumn{1}{c}{ Gram } & $\begin{array}{c}\text { Jumlah } \\
\text { Sampel }\end{array}$ & $\begin{array}{c}\text { Persentase } \\
\text { (\%) }\end{array}$ \\
\hline Gram positif & 4 & 20 \\
Gram negatif & 5 & 25 \\
$\begin{array}{l}\text { Gram positif dan } \\
\text { negatif }\end{array}$ & 11 & 55 \\
\hline \multicolumn{1}{c}{ Total } & 20 & 100 \\
\hline
\end{tabular}

Berdasarkan tabel yang disajikan dapat dilihat jumlah sampel terdiri dari 4 sampel gram positif (20\%), 5 sampel gram negatif (25\%), dan 11 sampel gram positif dan negatif (55\%).
Tabel 2. Hasil biakan bakteri dari air minum isi ulang di kota Manado

\begin{tabular}{lcc}
\hline Bakteri & $\mathrm{n}$ & $\mathbf{( \% )}$ \\
\hline Bacillus Subtilis & 14 & 42,42 \\
Shigella & 1 & 3,03 \\
Enterobacter Cloacae & 2 & 6,06 \\
Proteus Vulgaris & 7 & 21,21 \\
Streptococcus spp. & 1 & 3,03 \\
Enterobacter Agglomerans & 2 & 6,06 \\
Diplococcus & 1 & 3,03 \\
Pseudomonas spp. & 4 & 12,12 \\
Staphilococcus spp. & 1 & 3,03 \\
\hline \multicolumn{1}{c}{ Total } & 33 & 100 \\
\hline
\end{tabular}

Tabel 2 menunjukkan bahwa pada 20 sampel yang menunjukkan adanya pertumbuhan bakteri, 33 bakteri dimana 9 spesies bakteri terdiri dari 3 spesies gram positif dan 6 spesies gram negatif. Tiga spesies bakteri gram positif yang ditemukan yaitu Bacillus subtilis bertotal sampel 14 (42,42\%), Streptococcus spp. bertotal 1 sampel (3,03\%), dan Staphilococcus spp. bertotal 1 sampel (3,03\%) dan enam bakteri spesies gram negatif yaitu Shigella bertotal 1 sampel (3,03\%), Diplococcus bertotal 1 sampel (3,03\%), Enterobacter cloacae bertotal 2 sampel (6,06\%), Enterobacter agglomerans bertotal 2 sampel (6,06\%), Pseudomonas spp. bertotal 4 sampel (12,12\%), Proteus vulgaris bertotal 7 sampel (21,21\%).

\section{BAHASAN}

Bakteri-bakteri yang berhasil di identifikasi dari sampel yang diambil di depot air minum isi ulang kota Manado adalah Bacillus subtilis yang terbanyak yaitu 14 sampel (42,42\%), Proteus vulgaris ditemukan 7 sampel (21,21\%), Pseudomonasspp. ditemukan 4 sampel (12,12\%), Enterobacter cloacae ditemukan 2 sampel (6,06\%), Enterobacter agglomerans ditemukan 2 sampel (6,06\%), Shigella, Streptococcus spp., Diplococcus, dan Staphilococcus spp. masing-masing ditemukan 1 sampel (3,03\%).

Hasil penelitian ini sesuai dengan penelitian yang dilakukan oleh Risky dkk tentang Analisis Kualitatif Kandungan 
Eschericia Coli Dan Coliform Pada 3 Depot Air Minum Isi Ulang Di Kota Manado ditemukan bakteri coliform pada 3 depot air minum isi ulang tersebut tapi hasil penelitian ini tidak sesuai dengan penelitian yang dilakukan oleh Maksum dkk tentang Pemeriksaan Bakteriologis Air Minum Isi Ulang di Beberapa Depot Air Minum Isi Ulang di Daerah Lenteng Agung dan Srengseng Sawah Jakarta Selatan., ${ }^{6,10}$ Penelitian Maksum dkk tidak ditemukan bakteri coliform. Penelitian Maksum dkk hanya ditemukan spesies Staphilococcus aureus sebanyak 4 sampel dari total 13 sampel. ${ }^{10}$ Penelitian yang dilakukan oleh Maulita Cut Nuria dari 25 sampel yang diperiksa, 24 sampel tidak mengandung E. coli (96\%) dan 1 sampel mengandung $E$. coli (4\%). ${ }^{11}$ Pada penelitian ini tidak ditemukan sampel yang mengandung E. coli. Perbedaan hasil ini disebabkan oleh karena lokasi yang berbeda.

\section{SIMPULAN}

Dari penelitian yang dilakukan tentang Identifikasi Bakteri pada Air Minum Isi Ulang di Kota Manado dapat diambil kesimpulan sebagai berikut:

1. Pemeriksaan bakteri dari 20 sampel air yang diperiksa, ditemukan semua sampel menunjukkan pertumbuhan bakteri. Bakteri Gram positif yang ditemukan pada kultur yaitu 4 sampel, bakteri Gram negatif yang ditemukan yaitu 5 sampel dan campuran bakteri Gram positif dan negatif yang ditemukan yaitu 11 sampel.

2. Jenis bakteri yang paling sering ditemukan adalah Bacillus subtilis.

\section{DAFTAR PUSTAKA}

1. Mukaromah AH, Yusrin. Pengaruh lama waktu simpan pada suhu ruang $\left(27-29^{\circ} \mathrm{C}\right)$ terhadap kadar zat organik pada air minum isi ulang. Prosiding Seminar Nasional Unimus; 2010: 50.

2. Rahayu A. Deteksi adanya bakteri pada air minum dalam galon. Jurnal Ilmiah
Kedokteran Universitas Wijaya Kusuma Surabaya. Januari 2010;2(1).

3. Asfawi S. Analisis faktor yang berhubungan dengan kualitas bakteriologis air minum isi ulang pada tingkat produsen di Kota Semarang Tahun 2004 [Tesis]. Semarang: Universitas Dipenogoro; 2004.

4. Peraturan Menteri Kesehatan Republik Indonesia Nomor 492/Menkes/PER/IV/2010 tentang Persyaratan Kualitas Air Minum. [cited at 2013 Sep 26]. Available from: http://pppl.depkes.go.id/_asset/_regulasi/53_ Permenkes\%20492.pdf.

5. Wandrivel R, Suharti N, Lestari Y. Kualitas air minum yang diproduksi di depot air minum isi ulang di Kecamatan Bungus Padang berdasarkan persyaratan mikrobiologi. Jurnal Kesehatan Andalas. 2012;1(3).

6. Tombeng RB, Polii B, Sinolungan S. Analisis kualitatif kandungan Eschericia Coli dan Coliform pada 3 depot air minum isi ulang di Kota Manado. Jurnal Kesehatan Masyarakat Universitas Sam Ratulangi. Agustus 2013;1(7).

7. Suprihatin B, Adriyani R. Higiene sanitasi depot air minum isi ulang Di Kecamatan Tanjung Redep Kabupaten Berau Kalimantan Timur. Jurnal Kesehatan Lingkungan. Januari 2008; 4(2):81-88.

8. Rubaiah A. Pengaruh nilai produk yang dirasakan terhadap proses keputusan pembelian konsumen air minum isi ulang pada depot Aloa Bandung. 2005.

9. Dinas Kesehatan Provinsi Sulawesi Utara Balai Data, Surveilans dan Sistem Informasi Kesehatan. Profil Kesehatan Provinsi Sulawesi Utara 2008. [cited at 2013 November 10]. Available from: http://www.depkes.go.id/downloads/profil/p rov_sulut_2008.pdf

10. Radji M, Oktavia H, Suryadi H. Pemeriksaan bakteriologis air minum isi ulang di beberapa depot air minum isi ulang di Daerah Lenteng Agung dan Srengseng Sawah Jakarta Selatan. Majalah Ilmu Kefarmasian. Agustus 2008;5(2).

11. Nuria MC, Rosyid A, Sumantri. Uji kandungan bakteri Escherichia coli pada air minum isi ulang dari depot air minum isi ulang di Kabupaten Rembang. Jurnal Ilmuilmu Pertanian. 2009;5(1):27-35. 